\author{
$P-607$ 前立腺形態維持における增殖因子の役割： \\ 前立腺無血清器官培萣による検討 \\ 愛知県がんセンター ${ }^{1)}, \mathrm{UCSF}^{21}$ \\ 杉村芳樹 $^{1)}$, 日置琭一 ${ }^{1)}$ ，小川和彦 ${ }^{1)}$, Hayward, S.W.' ${ }^{2)}$ Cunha, G.R. ${ }^{2)}$
}

（目的）前立腺上皮の増殖と形態維持はアンドロゲンに依存している。このアンドロゲン 作用において，各種増殖因子を介した上皮一間質細胞間の相互作用が注目されている。我々 は, 生直後の増殖期前立腺の無血清器官培養法により, KGFが腺管形態発生において重要な 役割を持つことを報告してきた。本研究では成長後の前立腺腺管を無血清器官培瀁し，前立 腺形態維持における増殖因子の役割を検討した。（材料と方法）成獣マウス前立腺の後側葉 を微小解剖し得られた前立腺腺管を無血清培養液上に浮かべたフィルター上にて 6 日間器官

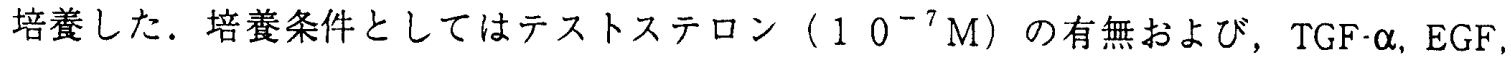
$a F G F, b F G F$ 添加し検討した。培養後の前立腺腺管の画像をコンピュータに取り込み腺管構 造の分枝距離を形態測定した。標本はホルマリン固定し，組織学的検討をするとともに ${ }^{3} \mathrm{H}$ - thymidineのラベリングにて增殖能を検討した。（結果と考察）テストステロンの存在下で はほほ正常の腺管構造と上皮細胞形態を認めたが，テストステロンの非存在下では培養腺管 は約 $30 \%$ が退縮し，残存した上皮細胞は分泌活性を認めなかった。テストステロンの非存 在下において各種増殖因子を添加した結果，TGF- $\alpha, \mathrm{EGF}, \mathrm{aFGF}$ は腺管の退縮に影響を与えな かったが，上皮の増殖および偏平上皮化成を誘導した，一方，bFGFは腺管の退縮を防止する とともに上皮形態を維持させた。 以上より，bFGFは成長後の前立腺形態維持においてアンド ロゲン作用に代わりうる重要な役割を持つことが示唆された。

\title{
$P-608$ 前立腺平滑筇細胞の形態学的検討
}

\author{
古屋病院、札幌医科大学泌尿器科教室 ${ }^{2)}$ \\ 古屋聖兒! 小椋 啓、田中吉則? 多森直哉? 塚本泰司 ${ }^{2)}$
}

前立腺肥大症 (BPH) においては、前立腺組織内に平滑筋細胞の增加とal pha-1受容体の增加が起きてい る。そして、alpha-1 受容体を介する平滑胘細胞の緊張収縮が、尿道抵抗を增加させると教えられてい る。そこで、前立腺肥大症では、どのくらい平滑筋細胞が增加しているのか、定量的形態計測を行った。 また、電子顕微鏡を用いて、前立腺平滑筋細胞の微細構造を検討した。

【対象と方法】BPH患者18例（A群）、およびほほ正常の前立腺組織を有する対照群10例（B群）である。 組織の定量的形態計測は、Weibelのtest gridを用いる方法と、前立腺 H-E 標本の光学影微鏡写真 (30 〜60視野)から、computerを用いた画像解析で測定する方法を用いた。間質、腺上皮、管空の\% vol ume を算出した。A群の12例、B群の3例に、アクチンの免疫組織化学的染色を行い、computer画假解析で間梊 に占める平滑筋細胞の \% volumeを算出した。A群の 4 例とB群の3 例において、前立腺平滑筥細胞の電顕 的樭察をおこなった。

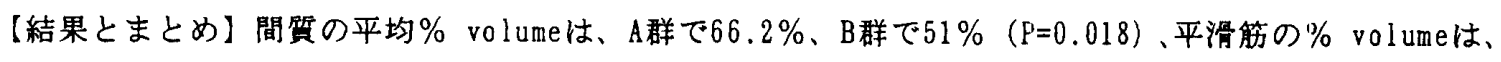
$\mathrm{A}$ 群で $46.3 \%$ 、B群で $40.8 \%(\mathrm{P}=0.002)$ であり、両群に有意の差を認めた。また; 前立腺肥大症と正常対 照の前立腺平滑筇細胞の電顕的䚁察では、細胞の形状、細胞内小器官の分布や数量などの微細構造の差 異を認めた。従って、前立腺肥大症においては、間質の增大、および正常とは形態的に異なる前立腺平 滑筋細胞の増加が認められ、これらが、非尿困難の機序に関与すると推定される。 